\title{
O DIREITO À AUTOIDENTIFICAÇÃO DOS POVOS INDÍGENAS COMO DIREITO FUNDAMENTAL
}

\author{
RIGHT TO SELF-IDENTIFICATION OF INDIGENOUS PEOPLES AS \\ FUNDAMENTAL RIGHT
}

\section{EL DERECHO A LA AUTOIDENTIFICACIÓN DE LOS PUEBLOS INDÍGENAS COMO DERECHO FUNDAMENTAL}

\author{
Pedro Pulzatto Peruzzo \\ https://orcid.org/0000-0001-5270-8674 / http://lattes.cnpq.br/5126921195345108 / peruzzopp@hotmail.com \\ Pontifícia Universidade Católica de Campinas- PUC \\ Campinas, SP, Brasil
}

GIULIA OZI

https://orcid.org/0000-0002-9619-7295 / http://lattes.cnpq.br/2453016670824695 / giuliaozi@hotmail.com Pontifícia Universidade Católica de Campinas- PUC Universidade Estadual de Campinas- UNICAMP Campinas, SP, Brasil.

\section{RESUMO}

O presente estudo propõe uma reflexão a respeito do direito à autoidentificação dos povos indígenas e da possibilidade de considerá-lo como direito fundamental. Temos como hipótese que ao eleger a democracia como regime de governo e ao dizer que os direitos e garantias expressos na Constituição não excluem outros decorrentes do regime e dos princípios por ela adotados, ou dos tratados internacionais em que o Brasil seja parte, o parágrafo $2^{\circ}$ do artigo $5^{\circ}$ da Carta Política alça o direito à autoidentificação previsto em documentos internacionais de direitos humanos ao estatuto de direito fundamental. Essa hipótese é desenvolvida neste artigo a partir de referenciais da Antropologia e da Ciência Política que debatem a centralidade da autoidentificação para o pleno gozo de outros direitos da personalidade, considerando nosso histórico colonial de anulação da dignidade de grupos culturalmente diferenciados.

Palavras-chave: Autoidentificação; povos indígenas; direito às diferenças; direito fundamental.

\begin{abstract}
The present study proposes a reflection on the right to self-identification of indigenous peoples and the possibility of considering it as fundamental right. We hypothesize that in electing democracy as a regime of government and in saying that the rights and guarantees expressed in the Constitution do not exclude others arising from the regime and the principles adopted by it, or of the international treaties to which Brazil is a party, the article 5 of the Brazilian Political Charter raises the right to self-identification provided for in international human rights documents to the status of fundamental right. This hypothesis will be developed in this article from the references of Anthropology and Political Science that debate the centrality of self-identification for the full enjoyment of other rights of the personality, considering our colonial history that nullified the dignity of culturally differentiated groups.
\end{abstract}

Keywords: Self-identification; indigenous peoples; right to differences; fundamental right.

\section{RESUMEN}

El presente estudio propone una reflexión acerca del derecho a la autoidentificación de los pueblos indígenas y de la posibilidad de considerarlo un derecho fundamental. Tenemos como hipótesis que al elegir la democracia como régimen de gobierno y al decir que los derechos y garantías expresados en la Constitución no excluyen otros derivados 
del régimen y de los principios por ella adoptados o de los tratados internacionales en que Brasil sea parte, el párrafo $2^{\circ}$ del artículo 5 de la Carta Política alza el derecho a la autoidentificación previsto en documentos internacionales de derechos humanos al estatuto de derecho fundamental. Esta hipótesis se desarrollará en este artículo a partir de referenciales de la Antropología y de la Ciencia Política que analizan la centralidad de la autoidentificación para el pleno goce de otros derechos de la personalidad, considerando nuestro histórico colonial de anulación de la dignidad de grupos culturalmente diferenciados.

Palabras clave: Autoidentificación; pueblos indígenas; derecho a las diferencias; derecho fundamental.

\section{SUMÁRIO}

INTRODUÇAO; 1 ANÁLISE HISTÓRICA: 0 ÍNDIO COMO OBSTÁCULO AO PROGRESSO; 2 AUTOIDENTIFICAÇÃO COMO UM DIREITO; 3 A IMPORTÂNCIA DA AUTOIDENTIFICAÇÃO PARA O EXERCÍCIO DA CIDADANIA; CONCLUSÃO; REFERÊNCIAS.

\section{INTRODUÇÃO'}

"Você não consegue me olhar e quando me olha não consegue me ver"2. Esse trecho de um rap do grupo Guarani Kaiowá BroMc's resume o objeto de reflexão deste artigo. A autoidentificação é um tema de grande relevância, principalmente quando abordado sob o contexto de países com a pluralidade cultural e o histórico colonial do Brasil.

A autoidentificação pode ser afirmada como um direito humano fundamental não apenas pelo papel que desempenha nas lutas por outros direitos sonegados aos povos indígenas ao longo de séculos, mas também por encontrar respaldo em tratados, pactos e convenções internacionais de direitos humanos assinados pelo Brasil, como a Convenção 169 da Organização Internacional do Trabalho ${ }^{3}$, a Convenção Americana de Direitos Humanos ${ }^{4}$ e a Declaração de Direitos dos Povos Indígenas da ONU ${ }^{5}$.

\footnotetext{
${ }^{1}$ Agradecemos imensamente as avaliações feitas pelos pares, que contribuíram muito para o aperfeiçoamento do estudo realizado, bem como a oportunidade de publicar o presente artigo na Revista Eletrônica do Curso de Direito da UFSM.

2BroMc's. Eju Orendive. Disponível em https://www.vagalume.com.br/bro-mcs/eju-orendive.html. Acesso em: 15 jun. 2020.

${ }^{3}$ A Convenção 169 da Organização Internacional do Trabalho (OIT) foi promulgada no Brasil pelo Decreto 5.051/2004. O artigo primeiro trata da autoidentificação ao afirmar que a autoidentificação como indígena ou tribal deverá ser considerada como critério fundamental para determinar os grupos aos quais se aplicam as disposições da presente Convenção.

${ }^{4}$ A Convenção Americana de Direitos Humanos foi promulgada pelo Decreto 678/1992 e seu artigo $3^{\circ}$ diz que toda pessoa tem direito ao reconhecimento de sua personalidade jurídica.

${ }^{5}$ A Declaração das Nações Unidas sobre os Direitos dos Povos Indígenas foi aprovada pela Organização das Nações Unidas em 2007, tendo o Brasil se comprometido a cumprir as determinações que nela estão previstas. No artigo $3^{\circ}$ diz: Os povos indígenas têm direito à autodeterminação. Em virtude desse direito determinam livremente sua condição política e buscam livremente seu desenvolvimento econômico, social e cultural.
} 
Os documentos internacionais de direitos humanos devem ser considerados na aplicação da Constituição, pois não apenas promovem uma integração do ordenamento jurídico de forma técnica, considerando o estatuto supralegal desses documentos ${ }^{6}$, mas também em razão do fato de que são nos organismos internacionais de direitos humanos que as minorias têm cada vez mais encontrado espaços mais abertos às múltiplas vozes dos atores locais e globais ${ }^{7}$. Daí a relevância de compreendermos a cooperação jurídica internacional não apenas como um resultado dos esforços dos Estados nacionais em negociar agendas globais. Mas especialmente como consequência do fortalecimento do protagonismo dos movimentos sociais e também do indivíduo como partes legítimas para provocar organismos internacionais, como é o caso da Comissão Interamericana de Direitos Humanos.

Apesar de não termos como objetivo o estudo da jurisprudência internacional sobre a autoidentificação, mas sim a reflexão desse direito numa perspectiva antropológica e política, é importante anotar a diferença que marca a forma como o Sistema Interamericano trata a personalidade jurídica como pré-requisito para o exercício de outros direitos e como a jurisprudência nacional desconsidera essa interdependência.

O direito à autodeclaração tem tanto uma dimensão cultural de pertencimento a um grupo étnico ou racial específico, como também uma dimensão subjetiva, relacionada à personalidade do sujeito que titulariza e luta por direitos. O direito à autodeclaração, nesse sentido, é um desdobramento do direito à personalidade jurídica, considerando a indispensabilidade da condição de índio para a legitimidade de muitas lutas por direitos, como as lutas por cotas e pela terra tradicional. A esse respeito, no caso da Comunidade Yakye Axa VS. Paraguai ${ }^{8}$, a Corte Interamericana de Direitos Humanos considerou que a concessão de personalidade jurídica serve para tornar operativos os direitos já existentes das comunidades

${ }^{6}$ BRASIL. Supremo Tribunal Federal. Acórdão que estabeleceu o estatuto supralegal dos tratados internacionais de direitos humanos. Recurso Extraordinário 466.343/SP. Disponível em: http://www.stf.jus.br/imprensa/pdf/re466343.pdf. Acesso em: 06 ago. 2018.

7"Essa vontade política discursivamente formada pode influenciar os processos formais de tomada de decisão do Estado, contribuindo para políticas públicas mais benéficas a grupos sociais mais vulneráveis. No entanto, por vezes estruturas nacionais não permitem que certos temas cheguem à esfera pública, ou se chegam, que sejam convertidos em políticas públicas oficiais, seja porque atendem a grupos sociais invisibilizados, ou porque desafiam grandes interesses econômicos ou por qualquer outro motivo. Nesses momentos, esferas públicas transnacionais podem ser determinantes." (BERNARDES, M. N. Sistema Interamericano de Direitos Humanos como Esfera Pública Transnacional: Aspectos Jurídicos e Políticos da Implementação de Decisões Internacionais. Sur. Revista Internacional de Direitos Humanos(Impresso), v. 15, p. 135-156, 2011).

${ }^{8}$ COSTA RICA. Corte Interamericana de Direitos Humanos. Caso comunidade Yakye Axa VS. Paraguai. Sentença de 17 de junho de 2005. Disponível em: http://www.corteidh.or.cr/. Acesso em: 15 jun. 2020. 
indígenas, que os vêm exercendo historicamente e não a partir de seu nascimento como pessoas jurídicas.

Ademais disso, quando o artigo $3^{\circ}$ da Convenção Americana de Direitos Humanos diz que toda pessoa tem direito ao reconhecimento de sua personalidade jurídica, a convenção confirma: 1- a maior abertura do SIDH para a ação direta de grupos e indivíduos culturalmente diferenciados independentemente de representação por instituições estatais ou outros intermediários que poderiam inviabilizar o acesso à Justiça no plano internacional e 2- afirma que a personalidade jurídica é um atributo de toda pessoa.

Assim, o presente estudo pretende avaliar a autoidentificação dos povos indígenas como decorrência lógica do direito à resistência contra a opressão, considerando a interdependência dos direitos humanos, analisando sua aplicação nos direitos como à terra, à cidade e outros. Sustentamos que a autoidentificação e os direitos com os quais ela se relaciona são considerados direitos fundamentais, de modo que ao integrarem esta categoria carregam consigo um histórico de luta sociais e exigem, por isso mesmo, uma análise também de sua dimensão política. Como define Joaquín Herrera Flores:

Os direitos humanos, em sua integralidade e a partir do universo normativo de resistência que defendemos, constituem algo mais que o conjunto de normas formais que os reconhecem e os garantem a um nível nacional ou internacional. Os direitos humanos como produtos culturais formam parte da tendência humana ancestral por construir e assegurar as condições sociais, políticas, econômicas e culturais que permitem aos seres humanos se perseverar na luta pela dignidade. ${ }^{9}$

A luta pela dignidade dos povos indígenas tem no direito à autoidentificação um dos seus alicerces, uma vez que esse direito está intimamente ligado ao conceito de identidade. A noção de identidade, segundo Roberto Cardoso de Oliveira, possui dois aspectos: a pessoal ou individual e a social ou coletiva, estando as duas noções interconectadas ${ }^{10}$. A identidade étnica está mais ligada à identidade social, de modo que é a afirmação do "nós" diante dos outros: [...] quando uma pessoa ou um grupo se afirmam como tais, o fazem como meio de diferenciação em relação a alguma pessoa ou grupo. ${ }^{11}$

Essa ideia pode, contudo, ser apropriada no jogo das relações de poder, fazendo com que, como aponta Boaventura de Souza Santos, seja necessário conhecer quem pergunta pela ${ }^{9}$ FLORES, J. H. Direitos humanos, interculturalidade e racionalidade de resistência. Sequência; Estudos Jurídicos e Políticos, 2009.p.191.

${ }^{10}$ CARDOSO DE OLIVEIRA, R. Identidade étnica, identificação e manipulação. Sociedade e Cultura, v. 6, n. 2, p. 117-131, 2007. P.120. Disponível em: https://www.redalyc.org/pdf/703/70360202.pdf. Acesso em: 15 jun. 2020.

${ }^{11}$ Id. Ibidem. 
identidade e quais são as intenções para se apropriar desse conceito ${ }^{12}$, posto que a pergunta pode se tornar uma forma de narcisismo e dominação ${ }^{13}$. Quando se trata da identidade indígena isso se torna ainda mais claro, já que por muito tempo eles foram ensinados a não afirmar quem eram e a negar essa identidade, que vai muito além do uso de adornos distintos dos que eram e são utilizados pelos europeus ou norte-americanos.

Durante a ditadura civil-militar muitos povos indígenas foram perseguidos e várias tentativas de dizimação de grupos foram empreendidas pelo Estado brasileiro. Esses fatos foram responsáveis não apenas pelo silenciamento das identidades, mas também por grandes fluxos migratórias de povos que encontraram nas periferias de grandes cidades um refúgio para seguirem sobrevivendo sob a única identidade autorizada, ou seja, de trabalhadores urbanos pauperizados. ${ }^{14}$

O Texto 5 - Violações de direitos humanos dos povos indígenas, do relatório final da Comissão Nacional da Verdade (2014), apresenta detalhes desse processo de genocídio e etnocídio que, além de não ter sido devidamente investigado e esclarecido até hoje, permanece sendo obscurecido pelo Estado brasileiro. Exemplo disso é o descaso com que o Judiciário, respaldado pela tese do marco temporal, gestada no Supremo Tribunal Federal, vem desconsiderando que os povos indígenas são vítimas de renitente esbulho na região oeste do país pelo menos desde a década de 40, quando o Serviço de Proteção ao Índio emitia declarações falsas de inexistência de povos indígenas em terras que seriam dadas a colonos. Como esclarece Eduardo Viveiros de Castro:

[...] ser índio não é uma questão de cocar de pena, urucum e arco e flecha, algo de aparente e evidente nesse sentido estereotipicante, mas sim uma questão de 'estado de espírito'. Um modo de ser e não um modo de aparecer. ${ }^{15}$

Assim sendo, a análise que propomos aqui tem o objetivo de demonstrar, com base em estudos antropológicos e políticos, a viabilidade e necessidade de consideração jurídica da autoidentificação como um direito fundamental.

\footnotetext{
${ }^{12}$ Cf. SANTOS, B. S. Pela mão de Alice: O social e o político na pós-modernidade. Porto: Edições Afrontamento, 1994.

${ }^{13} \mathrm{Cf}$. SAWAIA, Bader Burihan. Comunidade como ética e estética da existência. Uma reflexão Mediada pelo conceito de identidade. Psykhe, v. 8, n. 1, p. 19-25, 2011.

${ }^{14} \mathrm{Cf}$. SILVA FILHO, Eduardo Gomes da. Projetos de Desenvolvimento na Amazônia e a Resistência dos Waimiri-Atroari (1964-2014). Dissertação de Mestrado defendida na Universidade Federal do Amazonas, 2015.

${ }^{15}$ VIVEIROS DE CASTRO, E. No Brasil, todo mundo é índio, exceto quem não é. Entrevista. Disponível em: https://pib.socioambiental.org/files/file/PIB_institucional/ No_Brasil_todo_mundo_é_índio.pdf. Acesso em: 25 abr. 2017.
} 


\section{ANÁLISE HISTÓRICA: O ÍNDIO COMO OBSTÁCULO AO PROGRESSO.}

A história das Américas é também a história do massacre indígena. No Brasil, de território continental, grandes reservas de recursos naturais e poderosas oligarquias agrícolas, 0 desrespeito a tudo que diz respeito aos nativos, desde suas línguas às suas vidas, segue tragicamente firme. Neste tópico faremos uma breve retomada histórica para apresentar como o índio foi tratado pelas políticas do Estado brasileiro, tendo contra si, na maioria das vezes, não apenas o preconceito, mas a própria lei.

Estima-se que quando os europeus chegaram ao Brasil, em 1500, existiam cerca de 5.000.000 16 de indivíduos que, posteriormente, foram plasmados na categoria genérica "índios". Segundo o censo do IBGE de 2010, apenas 817.963 indivíduos se autodeclararam como indígenas, sendo que 502.783 vivem nas áreas rurais e 315.180 vivem nas áreas urbanas, indicando uma diminuição de mais de 4 milhões de habitantes.

A partir da chegada dos colonizadores, a população que aqui habitava passou a ser denominada como índio, já que os portugueses pensavam estar nas Índias, criando assim uma categoria com pouca ou nenhuma identidade para os povos originários. ${ }^{17}$ Considerando isto, é possível afirmar que índio é uma categoria colonialmente inventada, não representando, portanto, a multiplicidade e pluralidade dos povos que são refletidos por ela. Vivian Urquid trata dessa categorização colonial do "índio":

Índio é, antes que mais nada, uma categoria colonial e que como tal não pode ser utilizada como ferramenta descritiva, mas apenas na relação que estabelece com o colonizador. Em última instância, o índio é o colonizado e somente pode ser entendido pelas relações de domínio a que foi submetido pelo colonizador. ${ }^{18}$

Contudo, é inevitável assumir que esta categoria "índio" está posta na sociedade e na Constituição e será aqui utilizada da forma mais plural possível. Portanto, o presente estudo a considera e a partir dela sustenta a legitimidade e importância da autoidentificação. Diante disso, torna-se evidente que a forma com que os índios são pensados é histórica, como coloca Manuela Carneiro da Cunha:

\footnotetext{
16 OLIVEIRA, João Pacheco \& Rocha Freire, Carlos Augusto da. A Presença Indígena na Formação do Brasil. Brasília: SECAD/MEC; UNESCO; LACED/UFRJ. 2006.

17 GALEANO, E. Veias Abertas da América Latina. São Paulo: LPM, 2010.

${ }^{18}$ Bonfil Batalla na obra El Concepto de Índio en América utiliza os termos índio e indígena indistintamente. Após a Convenção 169 da OIT, criou-se o consenso de utilizar o conceito de indígena para designar o sujeito dos direitos humanos, sendo o termo índio descartado principalmente pela carga negativa que envolve esta noção (in URQUIDI, V. G. F. Descolonização e Estados Plurinacionais. $35^{\circ}$ Encontro Anual da Associação Nacional de Pós-Graduação e Pesquisa em Ciências Sociais, p. 1-30, 2011).
} 
0 pensamento indigenista, ou seja, como os índios são pensados pelos que os regiam - políticos, administrados ou missionários - é e sempre foi histórico. Sua historicidade significa que não intervêm na política indigenista apenas conveniências e expedientes - embora estes certamente tenham predominado na prática- mas todo um debate de ideias renovado a cada época por novas razões ao mesmo tempo religiosas ou filosóficas, políticas, sociais, jurídicas, em suma, todo um universo de representações. ${ }^{19}$

Dessa forma, entende-se que a análise histórica tem suma importância na compreensão do desenvolvimento dos direitos dos povos indígenas no Brasil e também no mundo, especialmente para aqueles que interpretam e aplicam direitos fundamentais, na medida em que considera os fatores políticos, econômicos, mas também toda a gama de interferências simbólicas que orientaram as relações de dominação.

O subjugo indígena pelos invasores coloniais não foi, como se poderia imaginar, consensual por parte dos brancos. Segundo Beatriz Perrone-Moisés, o conflito já se iniciava, desde o século $\mathrm{XVI}$, entre jesuítas e colonos, visto que os primeiros defendiam a liberdade dos índios, mas eram acusados pelos colonos de quererem apenas garantir seu controle absoluto sobre a mão-de-obra ${ }^{20}$.

Lê-se em Perrone-Moisés que, legalmente, a prática colonial a partir do final do século XVI foi de abordar os nativos com o auxílio dos padres, afirmando a liberdade e incentivando que se deslocassem as aldeias para locais pré-definidos, próximos a zonas de povoamento português. Aceitando a proposta, os indivíduos se tornavam índios amigos, aliciados para guerras e trabalho servil, sendo úteis pelo conhecimento do território e das línguas. A coação no "descimento", como era chamado esse processo, era expressamente proibida pela Coroa. Com a morada em terras controladas e coabitadas apenas por padres doutrinadores, a catequização se tornou mais fácil. Este tratamento, no entanto, não era cabido aos índios considerados hostis, aos quais a pena pela inimizade era a escravização legitimada pelas “guerras justas". ${ }^{21}$

\footnotetext{
${ }^{19}$ CUNHA, M. C. Cultura com aspas. São Paulo: Cosac, Naify, 2009. P.10.

${ }^{20}$ PERRONE-MOISÉS, B. Índios Livres e Índios Escravos: Os princípios da legislação indigenista do período colonial (séculos XVI a XVIII). CUNHA, Manuela Carneiro da (Org) et. al. História dos Índios no Brasil. 2. ed. São Paulo: Companhia das Letras, Fapesp, 1992. p. 16.

${ }^{21}$ As "guerras justas" para aprisionamento dos índios hostis tinham sua legislação baseada num imaginário difuso sobre práticas indígenas "bárbaras"- canibalismo, poligamia etc. Tal imaginário era sempre acionado em defesa dos interesses econômicos dos colonos. O confronto dos missionários com pajés supostamente demoníacos tinha raízes no imaginário medieval da luta cristã contra feiticeiros e bruxas. Daí encontrarmos uma iconografia recorrente de mulheres canibais nos textos dos cronistas muito distante da realidade. Há gravuras em que o canibalismo é associado às práticas demoníacas, tudo indicando a necessidade de uma intervenção salvadora, disciplinadora e exterior. Foi com base nessas representações, associadas a argumentações de distintas ordens, que se construiu a crença (que se naturalizou) do caráter filantrópico e humanitário da intervenção colonizadora. (OLIVEIRA, J. P; FREIRE, C. A. R. A Presença
} 
ISSN 1981-3694

(DOI): $10.5902 / 1981369434252$

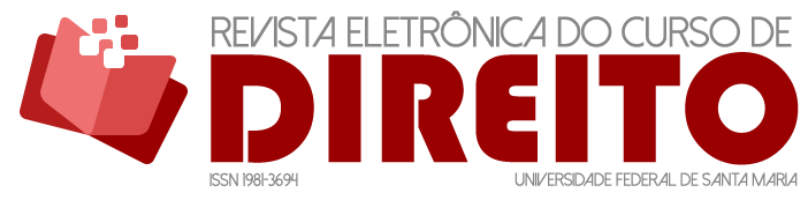

O DIREITO À AUTOIDENTIFICAÇÃO DOS POVOS INDÍGENAS COMO DIREITO FUNDAMENTAL

PEDRO PULZATTO PERUZZO GIULIA OZI

Esses aldeamentos serviam, sobretudo, para cumprir a realização do projeto colonial. Como afirma Perrone-Moisés, a [...] ocupação do território, sua defesa e uma constante reserva de mão de obra para o desenvolvimento econômico da colônia. ${ }^{22}$ Inicia-se na colônia, assim, um longo período no qual os índios deixavam de ter autonomia em suas escolhas, histórias e identidades, passando a sofrer manipulações externas justificadas pela lei.

Se eram difusos os interesses da própria colonização, não parece difusa a visão predominante sobre os nativos. Os povos originários eram considerados elementos despossuídos de razão e, por isso, deveriam ser incorporados aos sistemas sociais dos brancos, passando uma borracha sobre suas diferenças. Desde a época do Império, a política indigenista passou a fazer parte do Ministério da Agricultura, o que colocou na pauta do "desenvolvimentismo" a questão indígena. $O$ primeiro ato do Ministério da Agricultura foi extinguir todas as aldeias indígenas do Ceará $^{23}$, como se expressões culturais da humanidade pudessem ser extintas por meio de atos administrativos. Foi também no período imperial que a lei das terras (Lei 601 de 1850) foi criada. 0 artigo 12 dessa lei previa apenas a reserva de terras para a colonização dos indígenas.

Com essa regulamentação, o direito à terra tradicional passou a não ser mais admitido e o latifúndio foi oficializado, extinguindo dezenas de terras indígenas. Assim, o Império, mesmo significando o fim das guerras de extermínio, foi também a continuidade do processo de anulação das identidades indígenas e da oficialização do paternalismo estatal, paternalismo este reforçado pelo Estatuto do Índio de 1973.

A partir da proclamação da República, uma nova forma de lidar com as populações nativas se consolidou no Estado brasileiro, diferente da orientação do período imperial. Durante a primeira República, foi recriada a ideia da tutela em relação aos indígenas, subentendendo um conceito de ingenuidade, visão muito presente nos textos jurídicos e na literatura da época (e ainda hoje). Essa tutela buscou mudar a forma como se tratava juridicamente os índios, contrapondo o formato imperial, que promovia uma tutela orfanológica que os submetia ao "juiz de órfãos"24 em direção a uma perspectiva de que os indígenas possuíam condições mentais adversas e necessitariam da [...] presença do Estado na forma de direitos básicos, como educação e a simples convivência com o civilizado. ${ }^{25}$

Indígena na Formação do Brasil. Brasília: SECAD/MEC; UNESCO; LACED/UFRJ, 2006. Disponível em: http://www.dominiopublico.gov.br/download/texto/me004372.pdf. Acesso em: 02 mar. 2017.

22 ld. Ibidem.

${ }^{23}$ GOMES, M. P. Os Índios e o Brasil. Rio de Janeiro: Vozes, 1988.

${ }^{24}$ HANSEN, T. F. O pensamento jurídico sobre o indígena em períodos de modernização. Revista Direito \& Práxis, Rio de Janeiro, v. 06, n. 11, 2015, p. 326-347.

${ }^{25}$ Id. Ibdem. 
ISSN 1981-3694

(DOI): $10.5902 / 1981369434252$

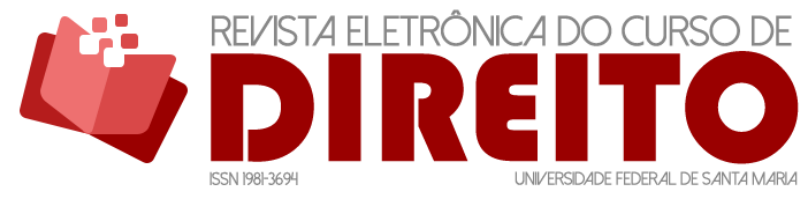

O DIREITO À AUTOIDENTIFICAÇÃO DOS POVOS INDÍGENAS COMO DIREITO FUNDAMENTAL

PEDRO PULZATTO PERUZZO GIULIA OZI

Roberto Cardoso de Oliveira (1972) afirma que, até pelo menos a metade do século XX, os preconceitos dominavam a formação do imaginário sobre os povos indígenas por parte dos não indígenas e pelo Estado, sendo que não haveria até então a formação de uma identidade por parte dos próprios índios, mas está sempre seria circundada por noções pré-concebidas e impostas, seja para valorizá-los, seja para desqualificá-los. ${ }^{26}$ Esta visão, segundo Hansen, dificultava qualquer avanço no sentido da construção de políticas públicas nas quais seus beneficiários participassem como agentes e não como destinatários passivos.

Após dois anos da proclamação da República, foi promulgada a Constituição da República dos Estados Unidos do Brasil, no dia 24 de fevereiro de 1891. Apesar da sua relevância para o momento político que o país vivia, esta Constituição não mencionava nada a respeito dos índios, desconsiderando deliberadamente sua existência. Para Cunha [...] o Brasil independente marca um retrocesso no reconhecimento dos direitos indígenas: no mesmo período em que o índio se torna o símbolo da nova nação "nega-se-lhe" tanto a soberania quanto a cidadania. ${ }^{27}$

Nesse contexto de retrocessos, na primeira década de 1900 a situação ficou ainda mais crítica para os povos indígenas, uma vez que as frentes de expansão para o interior aumentaram ao redor do Brasil e com isso os ataques contra os povos originários também. Outro fator agravante está ligado à declaração pública do então diretor do Museu Paulista, Rudolf Von Ihering, que afirmou ser a favor do extermínio dos indígenas que se colocassem como obstáculos à civilização. ${ }^{28}$

Diante desse cenário e após a acusação internacional de massacre dos povos indígenas no XVI Congresso dos Americanistas em Viena em 1908, criou-se pelo Decreto $n^{\circ}$. 8.072, de 20 de junho de 1910, o Serviço de Proteção aos Índios e Localização de Trabalhadores Nacionais $(\text { SPILTN })^{29}$. O objetivo deste órgão era dar assistência aos índios e fundar colônias agrícolas que se utilizariam da mão-de-obra indígena encontrada em expedições oficiais. Como se pensava que o índio era um ser transitório, que se tornaria trabalhador rural ou proletário urbano, nunca proprietário, obviamente, a integração das funções em um só órgão era ideal.

Influenciado pela perspectiva integracionista e classificatória, o Código Civil de 1916, criado durante a República, tratou da questão indígena em seu artigo $6^{\circ}$, considerando-os

\footnotetext{
${ }^{26}$ HANSEN, T. F. O pensamento jurídico sobre o indígena em períodos de modernização. Revista Direito \& Práxis, Rio de Janeiro, v. 06, n. 11, 2015, p. 326-347.

${ }^{27}$ CUNHA, M. C. Os Direitos do Índio: ensaios e documentos. São Paulo: Editora Brasiliense, 1987. P.63.

${ }^{28}$ Idem.
}

${ }^{29}$ Criação do Serviço de Proteção ao Índio (SPI). Disponível em https://pib.socioambiental.org/pt/c/politicas-indigenistas/orgao-indigenista-oficial/o-servico-deprotecao-aos-indios-(spi). Acesso em: 25 fev. 2017. 
incapazes relativamente a determinados atos ou ao modo de exercer estes atos: III - Os silvícolas [...] ficarão sujeitos ao regime tutelar, estabelecido em leis e regulamentos especiais, o qual cessará à medida que se forem adaptando à civilização do País”.

O Código Civil legalizou a condenação do índio a um estágio de menoridade involuntário e os excluiu da dita comunhão nacional, à qual deveriam ser integrados. A condição de ser indígena, do ponto de vista da República, foi caracterizada pelo pertencimento a um estágio social humano atrasado, atribuído aos índios por pessoas que desconheciam suas peculiaridades culturais e, assim, negavam suas identidades. Isso reforça a necessidade de compreender a autoidentificação com um direito fundamental, na medida em que assegura aos povos indígenas o direito a dizer quem são, ou seja, personalidade jurídica com dignidade, nos termos do que decidiu a Corte Interamericana no caso acima citado da comunidade Yakye Axa vs. Paraguai.

Dois anos após a criação do Código Civil, em 1918, o SPILTN tornou-se apenas SPI (Serviço de Proteção ao Índio) e o modo preconceituoso de pensar a identidade indígena continuou explícita. Um exemplo disso é a criação do Decreto n. 5.484 de 1928, que promoveu uma:

[...] ampliação dos poderes tutelares para o SPI, inclusive com sua capacidade de definir a condição indígena, a tutela passou a ser exercida pelo Estado e não mais pelo juiz de Órfãos (art. $5^{\circ}$ ), e enquanto não estivessem totalmente "incorporados" a sociedade brasileira [...]. ${ }^{30}$

Esta decisão oficial concedeu aos funcionários do SPI, sobretudo, o poder de dizer quem seria e quem não seria indígena, e abria espaço para as intermináveis redes de clientelas que articulariam, e até hoje articulam, o quadro nacional da administração indigenista. ${ }^{31} \mathrm{~A}$ consequência desta política, para além da insegurança jurídica, é que na prática a definição se tornou pontual e transitória, decorrente da individualidade de consciência dos funcionários que julgavam o ser indígena.

Vale ressaltar que no período de 1910 até 1967 (extinção do SPI) vigorou no Brasil diferentes Constituições: 1891, 1934, 1937, 1946 e 1967. Todas elas trataram da incorporação à comunhão nacional e foi essa política que deu ensejo ao esbulho renitente das terras indígenas e, em última instância, pelo genocídio e etnocídio desses povos.

\footnotetext{
${ }^{30}$ HANSEN, T. F. O pensamento jurídico sobre o indígena em períodos de modernização. Revista Direito \& Práxis, Rio de Janeiro, v. 06, n. 11, 2015, p. 326-347.

${ }^{31} / d$. Ibidem.
} 
A FUNAI, criada pela Lei 5731/1967, em substituição do SPI, dissolvido por acusações de corrupção ${ }^{32}$, passa ser a organização responsável pela tutela dos povos indígenas, assumindo as competências do SPI. Vinculada a interesses políticos das oligarquias nacionais, a FUNAI foi compelida a realizar suas ações de modo a ter como objetivo assimilar a cultura indígena à cultura da sociedade dita civilizada. Sua estruturação se deu seguindo o mesmo modelo do SPI ${ }^{33}$.

A inicial proposta da FUNAl, de elaborar seus projetos a partir de profissionais tecnicamente orientados e de interesses convergentes aos interesses indígenas não deu certo. A FUNAI trabalhava com o mesmo quadro funcional do SPI, com poucos recursos financeiros e pessoal pouco qualificado. Além disso, outro fator que dificultou ainda mais a execução da proposta inicial da FUNAl é que este órgão era vinculado ao Ministério do Interior, que tinha como missão o dito desenvolvimento:

Como Dalmo Dallari enfatizava à época, era uma contradição flagrante colocar um órgão que devia defender os direitos dos índios sob a autoridade de um ministério cuja missão era de "desenvolvimento", entendido da forma mais predatória possível. Os custos ambientais e sociais para a população em geral e para os índios em particular, eram considerados secundários, quando não simplesmente ignorados: assim entende-se que, nessa época, políticos e militares pudessem abertamente declarar que os índios eram "empecilhos para o desenvolvimento. ${ }^{34}$

Mesmo diante de tantas opressões e dificuldades, a década de 1970 foi fundamental para a questão indígena no Brasil. ${ }^{35}$ Segundo o programa Povos Indígenas do Brasil , a década abrangeu a criação e estruturação da maior parte das organizações de apoio ao movimento indígena, como as comissões pró-índio (CPIs), as associações nacionais de apoio ao índio (ANAls), o Conselho Indigenista Missionário (CIMI), o Centro de Trabalho Indigenista (CTI), a Operação Amazônia Nativa (OPAN), o Centro Ecumênico de Documentação e Informação (CEDI) $)^{36}$ e o Núcleo de Direitos Indígenas (NDI).

\footnotetext{
32 SANTILLI, J. (Org.). Os Direitos Indígenas e a Constituição. Porto Alegre, Fabris Editor, 1991.

${ }^{33}$ Idem.

${ }^{34}$ CUNHA, M. C. Política Indigenista no Século XIX. In: CUNHA, Manuela Carneiro da (Org) et. al. História dos Índios no Brasil. 2. ed. São Paulo, Companhia das Letras, Fapesp, 1992.p.100.

35 O ISA (Instituto socioambiental - "uma organização da sociedade civil brasileira sem fins lucrativos, para propor soluções de forma integrada a questões sociais e ambientais com foco central na defesa de bens e direitos sociais, coletivos e difusos relativos ao meio ambiente, ao patrimônio cultural, aos direitos humanos e dos povos)", criou o programa Povos Indígenas no Brasil (PIB), que trata especificamente da temática indígena brasileira. Para mais informações, conferir https://www.socioambiental.org/pt-br/oisa. Acesso em: 06 jan. 2018.

${ }^{36}$ O CEDI e o NDI, posteriormente, se juntaram e formaram o ISA. Essas organizações passaram a trabalhar em prol da questão indígena, promovendo ações e projetos que colaborassem com a interlocução entre todas as partes e facilitassem a relação entre os grupos. Já na década de 1980, "diversas manifestações indígenas passaram a ganhar visibilidade nacional. Também neste período começaram a se estruturar suas
} 
ISSN 1981-3694

(DOI): $10.5902 / 1981369434252$

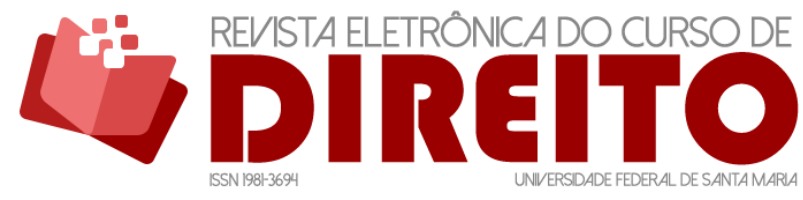

O DIREITO À AUTOIDENTIFICAÇÃO DOS POVOS INDÍGENAS COMO DIREITO FUNDAMENTAL

PEDRO PULZATTO PERUZZO GIULIA OZI

Apesar do surgimento de muitas organizações importantes, a décadas de 60 e 70 marcaram um período duro na história da luta indígena no Brasil. 0 governo militar tinha como uma de suas políticas a integração nacional da Amazônia, promovendo até mesmo um projeto oficial de extermínio que propunha o fim dos índios até o ano de $1998^{37}$, e o processo de ocupação da região, a partir dessas décadas, passa a ser feito de forma contínua tanto no tempo quanto na extensão do território.

É possível afirmar que durante a ditadura civil-militar os povos indígenas foram mais uma vez massacrados. Quanto à legislação, foi criado nesse período o Estatuto do Índio (Lei 6.001/73) que ainda hoje não foi revogado e nem declarado inconstitucional expressamente, especialmente o artigo $3^{\circ}$, que diz que "índio" é todo indivíduo de origem e ascendência précolombiana que se identifica e é identificado como pertencente a um grupo étnico cujas características culturais o distinguem da sociedade nacional. Apesar de a Convenção 169 da OIT (de estatuto supralegal) considerar a autoidentificação como critério fundamental, muitos magistrados ainda aplicam o Estatuto do Índio, como veremos adiante.

Após a criação do Estatuto, o próximo ponto relevante foi a Constituição de 1988, que teve um papel de suma importância na batalha por direitos dos povos indígenas trazendo um capítulo próprio para o tema. Ainda que as bancadas ruralistas estejam em franco processo de ataques ao texto constitucional para tornar inúteis esses direitos dos povos indígenas e o STF esteja validando muitos desses ataques, vide a tese do marco temporal, o artigo 231 da Carta prevê que são reconhecidos aos índios sua organização social, costumes, línguas, crenças e tradições, e os direitos originários sobre as terras que tradicionalmente ocupam, competindo à União demarcá-las, proteger e fazer respeitar todos os seus bens.

É possível, a partir da análise histórica desenvolvida, estabelecer que os anos entre 1973 e 1988 foram de ligeiro acomodamento da questão em seu âmbito jurídico. No entanto, a partir da marcante presença do tema na política nacional nas décadas de 60 e 70, os povos indígenas passaram a organizar iniciativas de afirmação mais fortes referentes à sua autonomia e apesar dessas iniciativas não terem sido revertidas imediatamente em atos normativos ou políticas públicas efetivas, serviram para não deixar a questão esquecida e contribuíram para avanços significativos na Constituição de 1988.

primeiras organizações formais de base comunitária ou regional. Em âmbito nacional foi criada a União das Nações Indígenas (ƯNI), que já não existe mais" (PIB, s/d).

${ }^{37}$ CARVALHO, P. et al. Amazônia indígena: conquistas e desafios. Estudos avançados, v. 19, n. 53, p. $237-$ 255, 2005. 


\section{AUTOIDENTIFICAÇÃO COMO DIREITO}

Vigente desde 1973, produto de um tempo de truculências institucionais de um governo militar, o Estatuto do Índio dispôs logo no artigo $1^{\circ}$ a integração dos povos indígenas a uma famigerada e questionável comunhão nacional: Art. $1^{\circ}$ Esta Lei regula a situação jurídica dos índios ou silvícolas e das comunidades indígenas, com o propósito de preservar a sua cultura e integrá-los, progressiva e harmoniosamente, à comunhão nacional. Nessa toada, o artigo $3^{\circ}$ diz que índio é todo indivíduo de origem e ascendência pré-colombiana que se identifica e é identificado como pertencente a um grupo étnico cujas características culturais o distinguem da sociedade nacional. Ou seja, além de terem sido excluídos do conceito de sociedade nacional, os indígenas deveriam ser integrados a esse corpo estranho.

0 relatório da Comissão Nacional da Verdade demonstra com provas documentais e até mesmo testemunhais as consequências dessa política, trazendo à tona dados ainda mais assustadores, como a tortura e o desaparecimento de índios que contrariavam o sistema de exploração imposto pela FUNAI ${ }^{38}$. O Ministro do Interior, Maurício Rangel Reis, do governo de Ernesto Geisel, deixa esse sentimento bastante claro em uma fala em 1976: Os índios não podem impedir a passagem do progresso[...], [...]dentro de 10 a 20 anos não haverá mais índios no Brasil. ${ }^{39}$

Nesse sentido, importante analisar como promover uma integração do ordenamento jurídico vigente de modo a assegurar a autodeterminação com respeito às diversidades dos povos originários. A Constituição de 1988 foi promulgada em um momento de redemocratização do país, contexto distinto ao da criação do Estatuto do Índio. Conhecida como Constituição Cidadã, nela as questões indígenas são abordadas a partir do princípio da autonomia ${ }^{40}$ dos povos,

\footnotetext{
${ }^{38}$ Segundo palavras do sertanista Antônio Cotrim Soares, jamais contestadas pela Funai, Crenaque "é um campo de concentração" para onde são enviados os índios revoltados com o sistema explorador e opressivo da Funai. A prisão é dirigida por um oficial da PM de Minas Gerais, comandando um destacamento de seis soldados. Os índios presos são obrigados a um regime de trabalho forçado de oito horas diárias. São colocados em prisões celulares, isolados uns dos outros. E recebem espancamentos e torturas. Cotrim conta o caso do índio Oscar Guarani, de Mato Grosso, que ao entrar na prisão pesava 90 quilos e de lá saiu pesando 60, além de apresentar marcas de sevícias no corpo (Comissão Nacional da Verdade, p. 203-264, 2014).

${ }^{39}$ BRASIL. Comissão Nacional da Verdade Relatório Final. Texto. Violações de direitos humanos dos povos indígenas. p. 203-264. Brasília, 2014.

${ }^{40}$ Como Gersem dos Santos Luciano esclarece: Em termos conceituais, autonomia é uma forma de exercício do direito à livre autodeterminação dos povos de acordo com o que estabelece o artigo 1 do Pacto Internacional dos Direitos Civis e Políticos, o que implica substancialmente o reconhecimento de autogoverno comunitário no âmbito de um Estado nacional. Autonomia, portanto, não é o mesmo que independência nem envolve soberania, elementos indispensáveis na integração de um Estado. Autonomia
} 
contrapondo-se ao ufanismo e ao discurso de integração nacional. Além de garantir a autodeterminação, é a partir da Constituição Federal de 1988 que o Estado reconhece o direito às diferenças (art. $3^{\circ}$, inciso IV), enaltecendo mais uma vez a mudança de perspectiva no campo legal:

Impõe-se ao Estado uma total inversão de suas ações, historicamente voltadas para a integração dos índios. Se até então a questão básica subjacente a todas as iniciativas estatais era o grau de integração ou de semelhança com nosso modo de vida, agora [...] é sobre as diferenças. ${ }^{41}$

Esta mudança, fundamental para o entendimento da questão, está explícita no artigo 231, que reconhece a organização social, costumes, línguas, crenças e tradições, sendo este um dos artigos mais importantes no que diz respeito ao direito indígena, pois é a validação constitucional do direito às diferenças. A relevância de um texto constitucional que legitima a diferença é enorme, pois o discurso do modelo universalista homogeneizador pode ser superado para dar lugar ao reconhecimento da heterogeneidade, calcada no que Rouanet ${ }^{42}$ denomina "universalismo concreto", ou seja, a possibilidade de:

Conviver com todas as diferenças, desde que elas respeitem um núcleo mínimo de normas e princípios comuns, de princípios universais aplicados a todas as culturas; a partir daí o pluralismo, a diversidade, as variedades culturais. Em outras palavras, todos os particularismos culturais podem florescer, contanto que se subordinem a uma cultura política comum, consubstanciada numa Constituição democrática. ${ }^{43}$

Assim, a promulgação de uma Constituição democrática nos permitiu afirmar a diferença como um direito, sendo [...] uma ampliação, no interior da cultura do direito, da

é uma entidade menor no interior de uma entidade maior única e soberana. É também uma forma de distribuição de competências nos distintos níveis de organização do governo e em torno de variadas atribuições políticas, econômicas, sociais e culturais (LUCIANO, G. S.O Índio Brasileiro: o que você precisa saber sobre os povos indígenas no Brasil de hoje. Brasília: Ministério da Educação, Secretaria de Educação Continuada, Alfabetização e Diversidade; LACED/Museu Nacional, 2006. p. 93).

${ }^{41}$ BRAND, A. Mudanças e continuísmos na política indigenista pós- 1988. Etnodesenvolvimento e políticas públicas: bases para uma nova política indigenista II. Rio de Janeiro: Contra Capa Livraria/LACED (2002). P.32

${ }^{42}$ Rouanet na obra "Universalismo concreto e diversidade cultural" apresenta a possibilidade de conflito na implementação do direito à diferença entre a cidadania universal inclusiva e a cidadania particular plural se partirmos de dois extremos polarizados que ele denomina como: igualitarismo abstrato e diferencialismo abstrato. No primeiro, a idéia, que tem origem na Revolução Francesa, é homogeneizar as culturas, impondo-se o padrão burguês ocidental. O segundo desconsidera nossa origem comum e é extremamente abstrato. Para solucionar a questão e não gerarmos conflitos na implementação do direito à diferença o autor apresenta o universalismo concreto (ROUANET, S. P. Universalismo concreto e diversidade cultural. Identidade e globalização: impasses e perspectivas da identidade e a diversidade cultural. Rio de Janeiro: Casa Rui Barbosa, p.99-112, 2005.).

${ }^{43}$ ROUANET, S. P. Universalismo concreto e diversidade cultural. In: Identidade e globalização: impasses e perspectivas da identidade e a diversidade cultural. Rio de Janeiro: Casa Rui Barbosa, 2005. P.108. 
afirmação de formas de luta por reconhecimento. ${ }^{44}$ Se ser diferente é um direito, o direito a se autodefinir, a se reconhecer e se afirmar como sujeito culturalmente diferenciado é um pressuposto. É nesse contexto constitucional que podemos afirmar que o direito à autoidentificação deve ser compreendido como genuíno direito fundamental.

0 artigo 231 da Constituição trata, ainda, sobre a demarcação de terras indígenas, questão complexa e imbricada a todas as outras pautas das comunidades. 0 acesso à terra está intimamente ligado ao direito à autoidentificação, uma vez que é se identificando como indígena que o indivíduo e seu grupo podem dar ensejo à reivindicação pela terra.

Outro aspecto importante está presente no artigo 232 da Constituição Federal, que prevê que os índios, suas comunidades e organizações são partes legítimas para ingressar em juízo em defesa de seus direitos e interesses. Este artigo traz uma inovação para o ordenamento, que até então tutelava os indígenas, de forma que não poderiam sequer defender seus direitos. Como bem coloca a antropóloga Alcida Ramos ${ }^{45}$, esse artigo tem o efeito de esvaziar um importantíssimo espaço que antes era ocupado pelas entidades de apoio ao índio, que se estendiam como pontes entre os índios e as instâncias políticas e jurídicas do país. Não obstante o avanço, também esse direito somente pode ser exercido plenamente na medida em que os indígenas tiverem o direito de se auto identificarem.

Além dos dispositivos já mencionados, vale salientar que o avanço em relação ao direito à identidade e diversidade cultural estão expressos nos artigos 215 e 216, sendo base essencial para o direito à autoidentificação:

Eles constituem base primordial do direito à autoidentificação, pois colocam como questão central para a identificação das comunidades não as diferenças culturais entre grupos percebidas por um observador externo, mas sim os "sinais diacríticos", isto é, aquelas diferenças que os próprios atores sociais consideram significativas e que, por sua vez, são revelados pelo próprio grupo. ${ }^{46}$

Garante-se no artigo 215 da Constituição o pleno exercício dos direitos culturais e acesso às fontes da cultura nacional e ainda impõe ao Estado o dever de proteção das manifestações culturais dos povos indígenas, das culturas populares e afro-brasileiras. 0 artigo 206 declara como patrimônio cultural brasileiro os modos de criar, fazer e viver, afirmando a

${ }^{44}$ BITTAR, E. C. B. Reconhecimento e direito à diferença: teoria crítica, diversidade e a cultura dos Direito Humanos. Revista da Faculdade de Direito, Universidade de São Paulo, v. 104, p. 551-565, 2009.

${ }^{45}$ RAMOS, $\quad$ A. $\quad$ R. 0 índio hiperreal. $\quad$ Disponível $\mathrm{em}$ http://www.anpocs.org.br/portal/publicacoes/rbcs_00_28/rbcs28_01.html. Acesso em: 05 jul. 2016.

${ }^{46}$ MOREIRA, E; PIMENTEL, M. O Direito à autoidentificação de povos e comunidades tradicionais no Brasil. Goiânia: Fragmentos da Cultura, v.25, p.159-170, abr./jun. 2015. Diponível em: http://seer.pucgoias.edu.br/index.php/fragmentos/article/view/4177. Acesso em: 23 jul. 2020. 
interculturalidade ${ }^{47}$, razão pela qual podemos afirmar que a Constituição Federal de 1988 busca a universalidade de confluência ${ }^{48}$, calcada em uma concepção racional, política, social, econômica e, sobretudo, cultural dos Direitos Humanos.

Os modos de vida são direitos constitucionais, o que torna as políticas integracionistas e a heteroidentificação previstas no Estatuto do Índio claramente inconstitucionais, pois apenas repetem os erros de uma política de Estado genocida.

Ainda nessa concepção de uma Constituição plural, Aloísio Krohling e Heleno Florindo da Silva analisam o avanço democrático das Constituições latino-americanas pelo que eles denominam como "novo constitucionalismo latino-americano":49

A constitucionalização da diversidade, portanto, principalmente, através desses recentes movimentos constitucionais latino-americanos ${ }^{50}$ (o brasileiro, em 1988; o colombiano, em 1991, o venezuelano, em 1999; o equatoriano, em 1994, mas sobretudo em 2008 e, por fim, o boliviano, em 2009) nos demonstra como o outro, violado, encoberto, esquecido, pode ser capaz de passar a figurar como sujeito importante para as decisões do Estado, não somente com o depósito de seu voto para a escolha de

\footnotetext{
${ }^{47}$ Importante salientar que a interculturalidade deve ser um instrumento crítico, ou como denomina Herrera Flores, um pilar de resistência, de libertação, de emancipação transformadora do Ser, pois: [...] ao mesmo tempo em que rechaçamos os essencialismos universalistas e particularistas, damos forma ao único essencialismo válido para uma visão complexa do real: aquele que cria condições para o desenvolvimento das potencialidades humanas [...], que se componha não de imposições ou exclusões, mas sim de generalidades compartilhadas às quais chegamos, não das quais partimos (FLORES, J. H. Direitos humanos, interculturalidade e racionalidade de resistência. Sequência: Estudos Jurídicos e Políticos, 2009. p.164).

${ }^{48}$ Universalismo de confluência é, para o autor, uma universalidade de chegada e não de partida: "nossa visão complexa dos direitos aposta por uma racionalidade de resistência. Uma racionalidade que não nega que é possível chegar a uma síntese universal das diferentes opções relativas aos direitos. E tampouco descarta a virtualidade das lutas pelo reconhecimento das diferenças étnicas ou de gênero. 0 que negamos é considerar o universal como um ponto de partida ou um campo de desencontros. Ao universal há de se chegar - universalismo de chegada ou de confluência - depois (não antes) de um processo conflitivo, discursivo de diálogo ou de confrontação no qual cheguem a romper-se os prejuízos e as linhas paralelas. Falamos do entrecruzamento, e não de uma mera superposição de propostas” (FLORES, J. H. Direitos humanos, interculturalidade e racionalidade de resistência. Sequência: Estudos Jurídicos e Políticos, 2009. p.25).

${ }^{49}$ Esse novo constitucionalismo latinoamericano, então, se constitui em uma teoria cujo objetivo é o avanço democrático da Constituição, e consequentemente, do Estado, abrindo espaço para novas arenas de debate, bem como para novos atores sociais, fruto de uma libertação/emancipação de seu julgo político, social e cultural, dos últimos séculos. (FLORINDO DA SILVA, H.; KROHLING, A. A interculturalidade dos direitos humanos e o novo constitucionalismo latino-americano- do universalismo de partida ao universalismo de chegada. Revista Quaestio luris, v. 9, n. 3, p. 1212-1237, 2016).

${ }^{50}$ As novas tendências constitucionais latinoamericanas, que buscam efetivar uma nova conotação à democracia moderna ao provocarem o que Santos (2007, p. 47) denominará de Demodiversidade, ou seja, a construção de uma democracia onde a diversidade cultural tenha voz e o poder necessário para se fazer presente nas arenas do debate político de seu povo, onde não ser igual é ser normal, e onde o diálogo possa ser efetivado sem a "pressa de uma decisão. (FLORINDO DA SILVA, H.; KROHLING, A. A interculturalidade dos direitos humanos e o novo constitucionalismo latino-americano- do universalismo de partida ao universalismo de chegada. Revista Quaestio luris, v. 9, n. 3, p. 1212-1237, 2016).
} 
representantes, mas como sujeito ativo, atuante, que deve e será ouvido no decorrer da história, importante no momento de interculturalizarmos a concepção monocultural e universal dos direitos humanos. ${ }^{51}$

Diversos tratados e declarações internacionais trataram das questões indígenas e, por serem coerentes com os ideais da Constituição Federal, foram promulgados pelo Brasil com o propósito de reforçar e alinhar o sentido dos direitos nela garantidos com os parâmetros globais de proteção e promoção do direito às diferenças. Dentre eles, um documento de extrema importância é a Convenção 169 da $\mathrm{OIT}^{52}$. Para o presente trabalho, o ponto de relevo está no artigo $1^{\circ}$, que afirma que a autoidentificação deve ser o critério fundamental para a definição dos grupos indígenas.

Outro documento internacional de relevância é a Declaração da Organização das Nações Unidas sobre os Direitos dos Povos Indígenas de $2007^{53}$. Apesar de não ser exequível diretamente no Judiciário ${ }^{54}$, essa declaração possui um texto bastante avançado e no artigo $3^{055}$, a

${ }^{51}$ FLORINDO DA SILVA, H.; KROHLING, A. A interculturalidade dos direitos humanos e o novo constitucionalismo latino-americano- do universalismo de partida ao universalismo de chegada. Revista Quaestio luris, v. 9, n. 3, p. 1212-1237, 2016).

${ }^{52}$ Trata-se da Convenção 169 sobre Povos Indígenas e Tribais em Países Independentes internalizada no Brasil pelo Decreto 5.051/04, que parte de dois princípios importantes, a saber, o reconhecimento de um povo como sujeito de direito, e do princípio de autodeterminação, entendido não no sentido do direito internacional de um povo que busca sua independência, mas compreendido como o direito que as comunidades indígenas têm de decidir o futuro das suas comunidades. (URQUIDI, V. G. F. Descolonização e Estados Plurinacionais. $35^{\circ}$ Encontro Anual da Associação Nacional de Pós-Graduação e Pesquisa em Ciências Sociais, p. 1-30, 2011).

${ }^{53} \mathrm{~A}$ Organização das Nações Unidas (ONU) começou a analisar a situação dos povos indígenas em âmbito mundial no final dos anos 70 , se deparando com a situação alarmante de dizimação dos povos indígenas (MATHIAS, F; YAMADA, E. Declaração da ONU sobre direitos dos povos indígenas. In: Povos Indígenas no Brasil. Disponível em: http://pib.socioambiental.org/pt/c/direitos/internacional/declaracao-da-onusobre-direitos-dospovos-indigenas. Acesso em: 15 abr. 2016). A partir disso, em 1982, foi criado um grupo de trabalho da ONU destinado exclusivamente a desenvolver ações ao redor do mundo visando atingir a população indígena. Contudo, apesar da importância de tais acontecimentos, as ações começaram a ser mais significantes a partir de 2002, quando foi criado o Fórum Permanente da ONU para assuntos indígenas, obrigando que os responsáveis pelos governos ouvissem os especialistas indigenistas e ainda debatessem a questão. Atualmente o Fórum desenvolve o importante papel de monitorar a implementação da Declaração dos Direitos dos Povos Indígenas, além de subsidiar o trabalho do Relator Especial da ONU sobre direitos humanos e liberdades fundamentais indígenas. 0 processo de estabelecimento da Declaração enfrentou alguns obstáculos, mesmo após passar pela Subcomissão de Prevenção de Discriminação e Proteção de Minorias da ONU, ficando parada na Comissão de Direitos Humanos de 1994 até 2006, fato que mostra mais uma vez a resistência dos povos indígenas na luta pelos seus direitos (CUNHA, M. C. Cultura com aspas. São Paulo: Cosac, Naify, 2009.). Após 12 anos de embate, as lideranças indígenas e os países entraram em um acordo, contudo a promulgação aconteceu só um ano depois (2007).

${ }^{54} \mathrm{As}$ declarações internacionais são compromissos gerais e, diferentemente dos pactos, das convenções e tratados, não passam pelo processo de internalização que, no Brasil, além da assinatura do Presidente da República, exige aprovação pelo Congresso Nacional e, para que seja exequível no Judiciário, exige também a promulgação através de Decreto Presidencial. 
autodeterminação garante aos povos indígenas o direito à liberdade de determinar sua condição política, assegurando com isso o pleno gozo de se autodeterminar.

A autodeterminação e, como consequência, autoidentificação, são direitos que visam assegurar e promover a cidadania dos povos originários, historicamente impedidos de dizerem quem eram, quem são e o que querem ser no futuro. Inicialmente, por serem considerados bárbaros, foram obrigados a abandonar a indianidade para se adequarem a uma imagem edênica do invasor colonial. Depois foram obrigados a se enquadrarem em outra categoria estranha, ou seja, de trabalhador sempre pobre, é importante frisar. Ainda hoje o indígena que usa um celular é questionado a respeito de sua indianidade, ainda que nenhum europeu tenha se transformado em indígena pelo fato de fazer uso e de patentear ilegalmente conhecimento tradicional indígena. ${ }^{56}$

Além da Convenção 169 e da Declaração da Organização das Nações Unidas sobre os Direitos dos Povos Indígenas, outros tratados internacionais se aplicam a estes povos no que diz respeito ao direito a autoidentificação e outros direitos essenciais ao pleno exercício da cidadania, com ao consulta prévia ${ }^{57}$, a definir sua condição política e a participar, como indígenas, dos assuntos públicos do país: o Pacto Internacional de Direitos Econômicos, Sociais e Culturais (promulgado pelo Decreto 591/1992); o Pacto Internacional de Direitos Civis e Políticos (promulgado pelo Decreto 592/1992); a Convenção para a Eliminação da Discriminação Racial (promulgada pelo Decreto 65.810/1969); a Convenção das Nações Unidas sobre os Direitos da Criança (promulgada pelo Decreto 99.710/1990); a Convenção da Diversidade Biológica (promulgada pelo Decreto 2.519/1998); Convenção sobre a Proteção e Promoção da Diversidade Culturais (promulgada pelo Decreto 6.177/2007); Convenção Americana de Direitos Humanos (promulgada pelo Decreto 678/1992).

Como afirmam Baraldi e Peruzzo, sem a experiência da alteridade, que nos permite compreender as nossas diferenças a partir das diferenças dos outros, os instrumentos e foros de participação social podem acabar figurando como meras reproduções de uma lógica excludente

\footnotetext{
${ }^{55}$ Os povos indígenas têm direito à autodeterminação. Em virtude desse direito determinam livremente sua condição política e buscam livremente seu desenvolvimento econômico, social e cultural.

${ }^{56} \mathrm{Cf}$. PERUZZO, P. P. Direitos humanos, povos indígenas e interculturalidade. Revista Videre (ON LINE), v. 8, p. 4-18, 2016. Disponível em: http://ojs.ufgd.edu.br/index.php/videre/article/view/5594. Acesso em: 15 jun. 2020. Cf. também LAGO ALBUQUERQUE, Antonio Armando. Multiculturalismo e direito à autodeterminação dos Povos Indígenas. Porto Alegre: Sergio Antonio Fabris, 2008.

${ }^{57} \mathrm{Cf}$. PERUZZO, P. P. Direito à consulta prévia aos povos indígenas no Brasil. Direito \& Praxis, v. 8, p. 133, 2017. Disponível em: https://www.scielo.br/scielo.php?script=sci_arttext\&pid=S2179$89662017000402708 \& \operatorname{lng}=p t \& t \operatorname{lng}=$ t. . Acesso em: $10 \mathrm{fev} .2020$.
} 
já presente na estrutura social brasileir ${ }^{58}$. Ao garantir o direito à autoidentificação, portanto, garante-se também o respeito à diferença.

Além de garantir o direito à diferença, a efetivação do direito à autoidentificação é uma forma de resistência, sendo aqui considerada como decorrência lógica do direito à resistência contra a opressão, pois traduz o direito a ser considerado sujeito, e não objeto. 0 direito à resistência contra opressão está, historicamente, previsto em diplomas legais de suma importância para a construção dos direitos humanos, como a Declaração de Direitos do Homem e do Cidadão de 1789 (artigo 2º ), a Declaração Francesa de 1793 (artigo 23) e a Lei Fundamental da República Federal da Alemanha (artigo 20).

o direito à resistência é fundamental para o exercício da cidadania e para a participação política, pois sem esse direito e diante de situações de opressão, os indivíduos e grupos ficam algemados em um conjunto restrito de possibilidades. Nessa linha, ainda que não exista na Constituição de 1988 o reconhecimento expresso desse direito, podemos dizer que ele decorre do regime e dos princípios por ela adotados, nos termos do artigo $5^{\circ}$, § $2^{\circ}$.

Os processos cada vez mais intensos de criminalização dos movimentos sociais e, no caso dos povos indígenas, de encarceramento e assassinato de lideranças, evidencia a relevância de afirmarmos a todo tempo a validade e legitimidade desse direito. Em outros termos, sem o direito de resistir contra a opressão o que se extermina é o potencial criativo de quem sofre a opressão, sua autonomia e até seu direito de existir. Resistir contra a opressão é, portanto, agir em legítima defesa como sujeito não apenas em relação a uma agressão pontual, mas em relação a agressões permanentes que se perpetuam na história de um indivíduo ou de um povo.

Se autodeterminar, dizer sobre si mesmo, é uma das formas mais genuínas de resistir ao que ainda resta de colonialismo ${ }^{59}$ no Brasil (e resta muito, como veremos a seguir) e exercer plenamente a cidadania.

\footnotetext{
${ }^{58}$ Cf. BARALDI, C. B. F. PERUZZO, P. P. Democracia e Direitos Humanos: a participação social das minorias. Revista Eletrônica do Curso de Direito da UFSM, Santa Maria, RS, v. 10, n. 1, p. 347-370, out. 2015. Disponível em: https://periodicos.ufsm.br/revistadireito/article/view/19769. Acesso em: 15 jun. 2020.

${ }^{59}$ Trabalhamos o colonialismo não apenas como o processo de espoliação do território e dos povos tradicionais, mas também como o modelo de perpetuação de um sistema de produção e consumo vigente em países como o Brasil. Definição precisa pode ser encontrada em Gonzalez Casanova: A definição do colonialismo interno está originalmente ligada a fenômenos de conquista, em que as populações de nativos não são exterminadas e formam parte, primeiro do Estado colonizador e depois do Estado que adquire uma independência formal, ou que inicia um processo de libertação, de transição para o socialismo, ou de recolonização e regresso ao capitalismo neoliberal. Os povos, minorias ou nações colonizadas pelo Estado-nação sofrem condições semelhantes às que os caracterizam no colonialismo e no neocolonialismo em nível internacional: 1) habitam em um território sem governo próprio; 2) encontramse em situação de desigualdade frente às elites das etnias dominantes e das classes que as integram; 3 ) sua administração e responsabilidade jurídico-política concernem às etnias dominantes, às burguesias e
} 


\section{A IMPORTÂNCIA DA AUTOIDENTIFICAÇÃO PARA O EXERCÍCIO DA}

\section{CIDADANIA}

Apesar de o ordenamento jurídico ser extremamente claro em relação ao direito à autoidentificação, uma vez que a Convenção 169 da OIT, de estatuto supralegal, diz tratar-se de "critério fundamental", a realidade brasileira muitas vezes ignora este direito. Eduardo Bittar diz a esse respeito: "Vive-se um estado de coisas em que a lei não impregna o cotidiano, e, por isso, remanesce como letra-da-lei, enquanto as relações se fazem apesar-da-lei" ${ }^{60}$

A própria FUNAl tem recusado reconhecer o direito à autoidentificação ${ }^{61}$, mas considerado o histórico do órgão indigenista e a manipulação de seus postos de direção ${ }^{62}$, isso não é novidade. A situação fica mais grave quando nos deparamos com decisões judiciais que ainda aplicam o Estatuto do Índio para legitimar sua fundamentação, desconsiderando o que dispõe a Constituição Federal e a Convenção 169 da OIT sobre autoidentificação, normas hierarquicamente superiores.

Em 2014, uma decisão do juiz federal José Airton de Aguiar Portela ${ }^{63}$ determinou, em primeira instância, que o relatório produzido pela FUNAl delimitando a área de 42 mil hectares

oligarquias do governo central ou aos aliados e subordinados do mesmo; 4) seus habitantes não participam dos mais altos cargos políticos e militares do governo central, salvo em condição de "assimilados"; 5) os direitos de seus habitantes, sua situação econômica, política social e cultural são regulados e impostos pelo governo central; 6) em geral os colonizados no interior de um Estado-nação pertencem a uma "raça" distinta da que domina o governo nacional e que é considerada "inferior", ou ao cabo convertida em um símbolo "libertador" que forma parte da demagogia estatal; 7) a maioria dos colonizados pertence a uma cultura distinta e não fala a língua "nacional". Se como afirmara Marx "um país se enriquece às custas de outro país" igual a "uma classe se enriquece às custas de outra classe", em muitos Estados-nação que provêm da conquista de territórios, chame-se Impérios ou Repúblicas, a essas duas formas de enriquecimento juntam-se as do colonialismo interno (Marx, 1963: 155, Tomo I). (GONZÁLEZ CASANOVA, P. Colonialismo interno (uma redefinição). A teoria marxista hoje. Problemas e perspectivas. Boron, Atilio A.; Amadeo, Javier; Gonzalez, Sabrina. (org.).CLACSO, Consejo Latinoamericano de Ciencias Sociales. 2007. p. 431-458.)

${ }^{60}$ BITTAR, E. C. B. O Decreto 8.243/2014 e os desafios da consolidação democrática brasileira. In. Revista de Informação Legislativa (online). v. 51. n. 203, p. 7-38 ,jul/set, 2014. Disponível em:

http://www2.senado.leg.br/bdsf/item/id/507403. Acesso em: 06 ago. 2018.

${ }^{61}$ Conferir denúncia feita por OZI e PERUZZO (2017) com o título "FUNAI nega direito à autodeclaração aos povos indígenas". Disponível em: http://justificando.com/2017/08/18/funai-nega-direito-autodeclaracaoaos-povos-indigenas/. Acesso em: 08 ago. 2018.

${ }^{62} \mathrm{Cf}$. artigo da Folha de São Paulo, com título Exonerado, ex-chefe da Funai ataca governo e fala em 'ditadura'. Disponível em: http://www1.folha.uol.com.br/poder/2017/05/1881355-exonerado-ex-chefeda-funai-ataca-governo-e-fala-em-ditadura.shtml. Acesso em: 06 jun. 2018.

${ }^{63}$ Sentença proferida no processo $N^{\circ}$ 0000610-82.2010.4.01.3902 (Número antigo: 2010.39.02.000249-0), $2^{\mathrm{a}}$ VARA FEDERAL - Pará ( $\mathrm{N}^{\circ}$ de registro e-CVD 00107.2015.00023902.1.00582/00032). 
como terra indígena não possuía nenhuma validade jurídica, alegando que na região localizada no oeste do Pará não habitavam indígenas e sim ribeirinhos, aplicando o critério do Estatuto do Índio (heteroidentificação). Esse juiz olvidou a autodeclaração dos indígenas, disse que na região da Vila de Alter do Chão não há mais índios Boraris e decidiu:

b.2) Declarar não atendidos dois dos três requisitos indispensáveis (relacionados pela lei n. $6.001 / 1973$, em seu art. $3^{\circ}$ ) para que a condição jurídica de índio seja reconhecida, a saber: 1) origem e ascendência pré-colombiana; 2) ser identificado como pertencente a um grupo étnico cujas características culturais o distinguem da sociedade nacional. ${ }^{64}$

Após dois anos de conflitos intensos, no dia 20/01/2016, o Tribunal Regional Federal da $1^{\text {a }}$ Região anulou a sentença, mas mesmo assim as terras ainda não foram demarcadas e a região continua sendo cenário de conflitos. Para o cacique Dadá Borari, da Aldeia Novo Lugar, localizada na região mencionada da Terra Indígena Maro: "Diria que temos o direito de sermos tratados como cidadãos brasileiros, temos o direito à vida com dignidade e não podemos ser vistos como intrusos ou como entraves para o progresso". ${ }^{65}$

Além dos casos em que as decisões judiciais e órgãos indigenistas do Estado reforçam a repetição de práticas discriminatórias, figuras políticas de relevo também direcionam seus discursos nesse sentido, como, por exemplo, o ex-deputado constituinte Tito Costa que afirmou na petição inicial da ação para reintegração de posse da aldeia indígena Jaraguá que os índios "são invasores ridiculamente fantasiados com cabeça de vaca e arco e flecha"

Esse tipo de discurso comprova que, ainda hoje, o índio é definido com base em concepções preconceituosas que os consideram entraves para a expansão de uma ideia colonial de progresso. Nesse último caso, a aldeia indígena do Jaraguá teve uma área de 532 hectares declarada pela FUNAI como terra tradicionalmente habitada por Guaranis (Relatório Circunstanciado de Identificação e Delimitação da Terra Indígena publicado no Diário Oficial da União em 30/04/2013). Ocorre que em razão da dificuldade de conclusão do processo de demarcação e homologação, cerca de 600 indígenas continuam vivendo numa área de apenas 1,7 hectares.

Além de contrariarem o que está previsto no ordenamento jurídico brasileiro, tais decisões andam na contramão de julgados da Corte Interamericana de Direitos Humanos que,

\footnotetext{
${ }^{64}$ Integra da sentença em: http://www.prpa.mpf.mp.br/news/2015/arquivos/Sentenca_TI_Maro.pdf.

${ }^{65} \mathrm{Em}$ entrevista concedida a Mary Cohen. Disponível em: http: / / terradedireitos.org.br/2016/06/02/amazonia-real-os-direitos-humanos-e-o-meio-ambiente-naamazonia-entrevista-com-dada-borari/. Acesso em: 22 jul. 2020.

${ }^{66}$ Ação de reintegração de posse 0028364-20.2005.4.03.6100.
} 
além de vincularem o Brasil $^{67}$, reconhecem o direito à autodeclaração ao legitimarem o direito à personalidade jurídica. Como mencionado, o primeiro decorre do segundo, na medida que a condição de índio para a legitimidade de muitas lutas por direitos é indispensável.

Em decisão importante no caso do povo indígena Xákmok Kásek ${ }^{68}$, a Corte Interamericana definiu que o Estado Paraguaio violou o artigo $3^{\circ}$ da Convenção Americana de Direitos Humanos sob os seguintes fundamentos:

\begin{abstract}
Encuanto al derecho al reconocimiento de La personalidad jurídica, la Corte concluyó que,si bien el Estado había realizado esfuerzos para superar La situación de sub-registro de los miembros de La Comunidad, no había garantizado El acceso adecuado a los procedimientos de registro civil, atendiendo a la particular situación de vida que enfrentan los miembros de La Comunidad, a fin de lograr La expedición de documentos de identificación. Por lo anterior, la Corte declaró que el Estado violo El derecho consagrado em el artículo 3 (Derecho al Reconocimiento de laPersonalidad Jurídica) de La Convención Americana, em relación com el artículo 1.1 (Obligaciónde Respetar los Derechos) de La misma, em perjuicio de 19 personas integrantes de dicha Comunidad (Corte Interamericana, 2010).
\end{abstract}

A Corte determina, portanto, que o Estado deve afastar todos os obstáculos que possam impedir o exercício e gozo do direito à personalidade jurídica. 0 registro civil é apenas uma das formas de se autodeclarar indígena e os obstáculos podem aparecer tanto no momento de fazer a autodeclaração como no momento de escolher o nome de um filho, já que muitas vezes funcionários de cartório impedem a atribuição de nomes indígenas a crianças que serão registradas ${ }^{69}$.

O Tribunal Regional Federal da $3^{\mathrm{a}}$ Região, por exemplo, manteve a decisão de $1^{\mathrm{a}}$ Instância do processo 0001509-27.2016.4.03.6000 ${ }^{70}$, exigindo a apresentação da RANI (Registro Administrativo de Nascimento de Indígena) para "comprovar a condição de indígena" em

${ }^{67}$ O Brasil reconheceu a competência da Corte com a promulgação do Decreto 4.463/02. O reconhecimento
da competência da Corte Interamericana pelo Braisl é importante para várias outras lutas por direitos de
grupos minoritários, como é o caso das pessoas com deficiência. A esse respeito, PERUZZO, P. P.; LOPES,
L. S. . Afirmação e promoção do direito às diferenças da pessoa com deficiência e as contribuiçães do
Sistema Interamericano de Direitos Humanos. Revista eletrônica do curso de Direito da UFSM, v. 14, p.
1-33, 2019. Disponível em: https://periodicos.ufsm.br/revistadireito/article/view/35067. Acesso em: 23
jul. 2020. DOI: https://doi.org/10.5902/1981369435067.
${ }^{68} \mathrm{COSTA}$ RICA. Corte Interamericana de Direitos Humanos. Caso COmunidade indígena XákmokKásek V.
Paraguai. Disponível em: http://www.corteidh.or.cr/docs/casos/articulos/seriec_214_ing.pdf. Acesso em:
22 jul. 2020.
${ }^{69} \mathrm{Cf}$. artigo intitulado No Pará, dois mil indígenas cobram direito de usar nome étnico Disponível em:
https://www.brasildefato.com.br/2017/11/16/no-para-dois-mil-indigenas-cobram-direito-de-usar-nome-
etnico/. Acesso em: 07 jan. 2020 . da disponível em:
${ }^{70}$ Íntegra
da

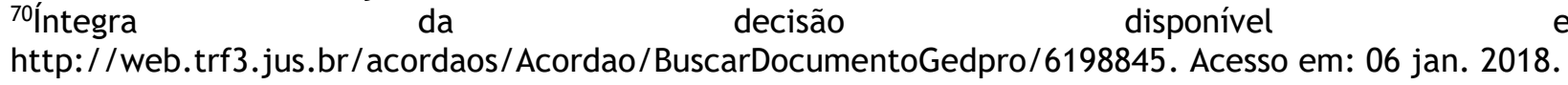


matrícula em Universidade Federal, sendo que tal documento é expedido pela FUNAl sob a exigência de diversos requisitos, como a heteroidentificação ${ }^{71}$.

Ao permitir que outras pessoas determinem quem é ou não o indivíduo ou grupo indígena abre-se uma margem para ferir outros direitos que deste são decorrentes, como aconteceu ao longo da história brasileira. Além disso, é a partir do direito à autoidentificação que o direito à resistência contra a opressão é fortalecido, sendo de suma importância sua existência para o exercício da cidadania. Em uma sociedade que define quem é ou não indígena a partir de discursos que proclamam que "índio que usa roupa não é índio”, a discussão sobre a autoidentificação é fundamental.

Assim, a partir da relação entre autoidentificação e cidadania, faz-se necessário salientar que ser tratado como cidadão e exercer esta cidadania está associado a diferentes fatores, como liberdade e respeito. Para Milton Santos, a consagração da cidadania é o respeito ao indivíduo, que se relaciona com uma série de princípios gerais e um corpo de direitos individualizados ${ }^{72}$. O geógrafo define a cidadania como "uma lei da sociedade que, sem distinção, atinge a todos e investe cada qual com a força de se ver respeitado contra a força, em qualquer circunstância"73, de modo que, assim como a liberdade, a cidadania não é uma dádiva, mas sim uma conquista.

Para a cidadania ser parte da vida social, ela deve estar presente na letra da lei, através de dispositivos institucionais que assegurem sua existência e a possibilidade de reclamação caso ocorra recusa desse direito. Nesse sentido, a cidadania é inerente a todos aqueles direitos conquistados nos processos de lutas sociais, com a aquisição de direitos políticos individuais, direitos coletivos e direitos sociais.

No contexto brasileiro foi a Constituição Federal de 1988 que passou a tratar a cidadania a partir dessa ótica. Na obra “Comentário contextual à Constituição", José Afonso da Silva explica que a Constituição traz uma nova dimensão da cidadania, em consonância com a previsão de direitos sociais que são a base para esta nova dimensão:

\footnotetext{
${ }^{71}$ Para expedição do RANI, o indivíduo deve apresentar uma declaração de pertencimento à um grupo de origem, o que, além de deslegitimar a autodeclaração, desconsidera absolutamente que: (1) muitas comunidades indígenas não vivem mais aldeadas por terem sido perseguidos desde a chegada dos portugueses; (2) os ataques truculentos sofridos durante a Ditadura Militar, como demonstra o relatório da Comissão Nacional da Verdade, gerando a dizimação dos povos; (3) e o sistema de estupros sistemáticos contado sob o eufemismo da miscigenação, que ocasionaram a quebra da história cultural e familiar de muitos descendentes de indígenas no Brasil, impossibilitando que muitos deles sejam identificados por um grupo de origem.
}

72SANTOS, M.[1987]. O Espaço do Cidadão. 7. ed. São Paulo: Universidade de São Paulo. 2012. P.19.

${ }^{73}$ Id. Ibdem. 
A nova ideia de cidadania se constrói, pois, sob o influxo do progressivo enriquecimento dos direitos fundamentais do homem. A Constituição de 1988, que assume as feições de uma Constituição dirigente, incorporou essa nova dimensão da cidadania quando, no art. $1^{\circ}$, II, a indicou como um dos fundamentos do Estado Democrático de Direito. A propósito, escrevemos: A cidadania está aqui num sentido mais amplo do que o de titular de direitos políticos. Qualifica os participantes da vida do Estado, o reconhecimento do indivíduo como pessoa integrada na sociedade estatal (art. $5^{\circ}$, LXXVII). Significa aí, também, que o funcionamento do Estado estará submetido à vontade popular. E aí o termo conexiona-se com o conceito de soberania popular ("parágrafo único", do art. $1^{\circ}$ ), com os direitos políticos (art. 14) e com o conceito de dignidade da pessoa humana (art. $1^{\circ}$, III), com os objetivos da educação (art. 205), como base e meta essencial do regime democrático. ${ }^{74}$

É nesta mesma ótica que Hannah Arendt desenvolveu, na obra "Origens do totalitarismo", uma ideia que se relaciona diretamente com a relação entre cidadania e direito: "Esta nova situação, na qual a 'humanidade"75 assumiu de fato um papel antes atribuído à natureza ou à história, significaria nesse contexto que o direito a ter direitos, ou o direito de cada indivíduo de pertencer à humanidade, deveria ser garantido pela própria humanidade" , de modo que humanidade faz referência à pluralidade humana. Ao afirmar que a pluralidade humana deveria garantir o direito a ter direitos, Arendt levanta a questão da cidadania, visto que é apenas através desta que podemos “ter acesso pleno à ordem jurídica”76.

Considerando a situação que os povos indígenas enfrentam desde a colonização, tornase evidente a importância desses povos afirmarem quem são no exercício da cidadania. A importância da autoidentificação para o exercício da cidadania reside no fato de que, ao se autoidentificar, o indivíduo tem, ao seu modo, acesso pleno aos direitos civis individuais e coletivos, essenciais para exercer a cidadania. Ao se identificar dentro de um grupo étnico e em relação a outros grupos é possível agregar força à luta por direitos e por uma organização política com a participação de todos, garantindo desde a efetivação de direitos como a consulta prévia até o direito á demarcação de terras, que já deveria ter sido finalizado em 1993 (artigo $67-\mathrm{ADCT})^{77}$.

A autoidentificação como pressuposto da cidadania exige a radicalização da própria noção de democracia, já que no limiar entre a ditadura da maioria e o autoritarismo da coerção,

\footnotetext{
${ }^{74}$ SILVA, José Afonso da. Comentário Contextual à Constituição. São Paulo: Malheiros, 5. ed. 2008. P.35. ${ }^{75}$ ARENDT, H. Origens do Totalitarismo - Antissemitismo, Imperialismo, Totalitarismo. Trad. Roberto Raposo. São Paulo: Companhia das Letras, 1989. P.332.

${ }^{76}$ LAFER, C. A reconstrução dos direitos humanos - Um diálogo com o pensamento de Hannah Arendt. São Paulo: Companhia das Letras, 1988. P.166.

${ }^{77}$ O Comitê para a Eliminação da Discriminação Racial da ONU conferiu prazo adicional até 2007 para a conclusão das demarcações (Cf. CERD/C/64/CO/2, de 28 de abril de 2004), porém também esse prazo não foi atendido.
} 
ISSN 1981-3694

(DOI): $10.5902 / 1981369434252$

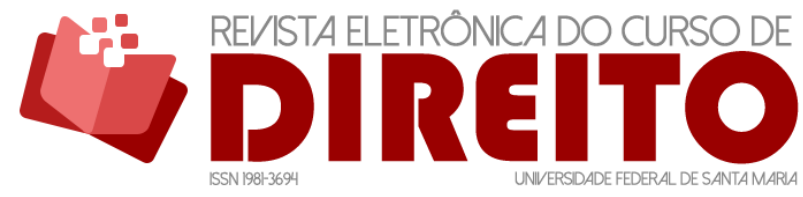

O DIREITO À AUTOIDENTIFICAÇÃO DOS POVOS INDÍGENAS COMO DIREITO FUNDAMENTAL

a dignidade de promover divergências no seio dos poderes da República ainda é algo a ser construído neste país, pois ainda é marcado em suas estruturas e seus preconceitos por fortes traços coloniais.

\section{CONCLUSÃO}

O contato do invasor colonial, em 1500, com os povos que já viviam no território que hoje denominamos Brasil, bem como todos os acontecimentos decorrentes desse evento, demonstram que a estrutura política estatal convergia, e permanece convergindo, para a dizimação dos povos indígenas, vistos como empecilho para o que os responsáveis pelo modo de produção vigente cunharam como progresso. Uma das formas mais eficientes de extermínio é negar aos povos indígenas o direito de se afirmarem como indígenas.

Como registra Vivian Urquid, “o componente indígena da nação foi desde o início desprezado e qualquer pressuposto de cidadania - seja a igualdade jurídica, civil ou política - lhe foi negado"78. Esse fato evidencia as dificuldades que os indígenas encontraram para resistir ao projeto colonial desde o começo da história de interação com o "homem branco", bem como evidencia que a proteção e promoção do direito a autoidentificação como um direito fundamental é imprescindível para que os indígenas exerçam sua cidadania de forma plena, resistindo contra toda forma de opressão.

Infelizmente, ainda hoje os agentes públicos seguem firmes no projeto de anular por completo os direitos dos povos indígenas. A autoidentificação deve ser entendida como um direito fundamental que, alinhado às agendas interamericanas de direitos humanos, garanta e promova outros direitos relacionados, como o acesso à terra tradicional, à educação diferenciada, à saúde e à participação nos assuntos públicos de um país pluricultural onde grupos social e culturalmente diferenciados dividem um mesmo espaço geográfico e político.

Assim sendo, o direito à autoidentificação deve ser afirmado e fortalecido não apenas pela viabilidade técnica demonstrada com base no ordenamento jurídico vigente e na jurisprudência nacional e internacional citada, mas também em razão do abismo real que existe entre a formação dos que formulam leis, políticas públicas e decisões judiciais baseadas em ficções como o Macunaíma ${ }^{79}$ e os cidadãos que lutam diuturnamente contra a pobreza, o

\footnotetext{
${ }^{78}$ URQUIDI, V. G. F. Descolonização e Estados Plurinacionais. $35^{\circ}$ Encontro Anual da Associação Nacional de Pós-Graduação e Pesquisa em Ciências Sociais, p. 1-30, 2011.

${ }^{79}$ ANDRADE, Mário de. Macunaíma. O herói sem nenhum caráter. Belo Horizonte: Itatiaia, 1987.
} 
preconceito e a discriminação para fazerem valer, na prática, a dignidade inerente a todos os seres humanos.

\section{REFERÊNCIAS}

ARENDT, H. Origens do Totalitarismo - Antissemitismo, Imperialismo, Totalitarismo. Trad. Roberto Raposo. São Paulo: Companhia das Letras, 1989.

BARALDI, C. B. F. PERUZZO, P. P. Democracia e Direitos Humanos: a participação social das minorias. Revista Eletrônica do Curso de Direito da UFSM, Santa Maria, RS, v. 10, n. 1, p. 347370, out. 2015. Disponível em: https://periodicos.ufsm.br/revistadireito/article/view/19769. Acesso em: 06 ago. 2018.

BERNARDES, M. N. Sistema Interamericano de Direitos Humanos como Esfera Pública Transnacional: Aspectos Jurídicos e Políticos da Implementação de Decisões Internacionais. Sur. Revista Internacional de Direitos Humanos(Impresso), v. 15, p. 135-156, 2011. p. 135-156.

BITTAR, E. C. B. Reconhecimento e direito à diferença: teoria crítica, diversidade e a cultura dos Direito Humanos. Revista da Faculdade de Direito, Universidade de São Paulo, v. 104, p. 551565, 2009.

BITTAR, E. C. B. O Decreto 8.243/2014 e os desafios da consolidação democrática brasileira. In. Revista de Informação Legislativa (online). v. 51. n. 203, p. 7-38 ,jul/set, 2014. Disponível em: http://www2.senado.leg.br/bdsf/item/id/507403. Acesso em: 06 ago. 2018.

BRAND, A. Mudanças e continuísmos na política indigenista pós- 1988. Etnodesenvolvimento e políticas públicas: bases para uma nova política indigenista II. Rio de Janeiro: Contra Capa Livraria/LACED (2002). Disponível em: http://laced.etc.br/site/arquivos/03-Estado-e-PovosIndigenas.pdf. Acesso em: 06 ago. 2018.

BRASIL. Comissão Nacional da Verdade Relatório Final. Texto. Violações de direitos humanos dos povos indígenas. p. 203-264. Brasília, 2014.

CARDOSO DE OLIVEIRA, R. A sociologia do Brasil indígena: ensaios. Rio de Janeiro, Tempo Brasileiro. São Paulo: Editora da USP, 1972.

CARDOSO DE OLIVEIRA, R. Identidade étnica, identificação e manipulação. Sociedade e Cultura, v. 6, n. 2, p. 117-131, 2007. P.120.

CARVALHO, P. et al. Amazônia indígena: conquistas e desafios. Estudos avançados, v. 19, n. 53, p. 237-255, 2005.

CUNHA, M. C. Os Direitos do Índio: ensaios e documentos. São Paulo: Brasiliense, 1987.

CUNHA, M. C. Política Indigenista no Século XIX. In: CUNHA, Manuela Carneiro da (Org) et. al. História dos Índios no Brasil. 2. ed. São Paulo: Companhia das Letras, Fapesp, 1992. 
CUNHA, M. C. Cultura com aspas. São Paulo: Cosac, Naify, 2009.

FLORINDO DA SILVA, H.; KROHLING, A. A interculturalidade dos direitos humanos e o novo constitucionalismo latino-americano- do universalismo de partida ao universalismo de chegada. Revista Quaestio luris, v. 9, n. 3, p. 1212-1237, 2016.

FLORES, J. H. Direitos humanos, interculturalidade e racionalidade de resistência. Sequência: Estudos Jurídicos e Políticos, 2009.

GALEANO, E. Veias Abertas da América Latina. São Paulo: LPM, 2010.

GOMES, M. P. Os Índios e o Brasil. Rio de Janeiro: Vozes, 1988.

GONZÁLEZ CASANOVA, P. Colonialismo interno (uma redefinição). In. Boron, Atilio A.; Amadeo, Javier; Gonzalez, Sabrina. (org.) A teoria marxista hoje. Problemas e perspectivas. CLACSO, Consejo Latinoamericano de Ciencias Sociales, p. 431-458, 2007.

HANSEN, T. F. O pensamento jurídico sobre o indígena em períodos de modernização. Revista Direito \& Práxis, Rio de Janeiro, v. 06, n. 11, p. 326-347, 2015.

LAGO ALBUQUERQUE, Antonio Armando. Multiculturalismo e direito à autodeterminação dos Povos Indígenas. Porto Alegre: Sergio Antonio Fabris, 2008.

LAFER, C. A reconstrução dos direitos humanos - Um diálogo com o pensamento de Hannah Arendt. São Paulo: Companhia das Letras, 1988.

LUCIANO, G. S.O Índio Brasileiro:o que você precisa saber sobre os povos indígenas no Brasil de hoje. Brasília: Ministério da Educação, Secretaria de Educação Continuada, Alfabetização e Diversidade; LACED/Museu Nacional, 2006.

MATHIAS, F; YAMADA, E. Declaração da ONU sobre direitos dos povos indígenas. In: Povos Indígenas no Brasil. Disponível em:

http://pib.socioambiental.org/pt/c/direitos/internacional/declaracao-da-onu-sobre-direitosdospovos-indigenas. Acesso em 08 ago. 2018.

MOREIRA, E; PIMENTEL, M. O Direito à autoidentificação de povos e comunidades tradicionais no Brasil. Goiânia: Fragmentos da Cultura, v.25, p.159-170, abr./jun. 2015. Diponível em:

http://seer.pucgoias.edu.br/index.php/fragmentos/article/view/4177. Acesso em: 23 jul. 2020. O’DWYER, E. C. Os quilombos do trombetas e do erepecuru-cuminá. In: Quilombos Identidade étnica e territorialidade. Rio de Janeiro: FGV, 2002.

OLIVEIRA, J. P; FREIRE, C. A. R. A Presença Indígena na Formação do Brasil. Brasília: SECAD/MEC; UNESCO; LACED/UFRJ, 2006. Disponível em: http://www.dominiopublico.gov.br/download/texto/me004372.pdf. Acesso em: 08 ago. 2018.

OZI, G. PERUZZO, P. FUNAI nega direito à autodeclaração aos povos indígenas. Disponível em: http: / /justificando.com/20L17/08/18/funai-nega-direito-autodeclaracao-aos-povos-indigenas/. Acesso em: 08 ago. 2018. 
PERRONE-MOISÉS, B. Índios Livres e Índios Escravos: Os princípios da legislação indigenista do período colonial (séculos XVI a XVIII). In: CUNHA, Manuela Carneiro da (Org) et. al. História dos Índios no Brasil. 2. ed. São Paulo: Companhia das Letras, Fapesp, 1992.

PERUZZO, P. P. Direitos humanos, povos indígenas e interculturalidade. Revista Videre (ON LINE), v. 8, p. 4-18, 2016. Disponível em:

http://ojs.ufgd.edu.br/index.php/videre/article/view/5594/3136. Acesso em: 23 jul. 2020. PERUZZO, P. P. Direito à consulta prévia aos povos indígenas no Brasil. Direito \& Praxis, v. 8, p. 1-33, 2017.

PERUZZO, P. P.; LOPES, L. S. . Afirmação e promoção do direito às diferenças da pessoa com deficiência e as contribuições do Sistema Interamericano de Direitos Humanos. Revista eletrônica do curso de Direito da UFSM, v. 14, p. 1-33, 2019.

DOI: https://doi.org/10.5902/1981369435067. Disponível em:

https://periodicos.ufsm.br/revistadireito/article/view/35067. Acesso em: 23 jul. 2020.

RAMOS, A. R. 0 índio hiperreal, s/d. Disponível em:

https://acervo.socioambiental.org/sites/default/files/documents/K1D00051.pdf. Acesso em: 23 jul. 2020.

ROUANET, S. P. Universalismo concreto e diversidade cultural. Identidade e globalização: impasses e perspectivas da identidade e a diversidade cultural. Rio de Janeiro: Casa Rui Barbosa, p.99-112, 2005.

SANTILLI, J. (Org.). Os Direitos Indígenas e a Constituição. Porto Alegre: Fabris, 1991.

SANTOS, B. S. Pela mão de Alice: 0 social e o político na pós-modernidade. Porto: Edições Afrontamento, 1994.

SANTOS, M.[1987]. O Espaço do Cidadão. 7.ed.São Paulo: Universidade de São Paulo. 2012.

SAWAIA, Bader Burihan. Comunidade como ética e estética da existência. Uma reflexão Mediada pelo conceito de identidade. Psykhe, v. 8, n. 1, p. 19-25, 2011.

SILVA, José Afonso da. Comentário Contextual à Constituição. São Paulo: Malheiros, 5. ed. 2008.

URQUIDI, V. G. F. Descolonização e Estados Plurinacionais. 35o Encontro Anual da Associação Nacional de Pós-Graduação e Pesquisa em Ciências Sociais, p. 1-30, 2011.

VIVEIROS DE CASTRO, E. No Brasil, todo mundo é índio, exceto quem não é. Entrevista. Disponível em:

https://pib.socioambiental.org/files/file/PIB_institucional/No_Brasil_todo_mundo_\%C3\%A9_\%C3 \%ADndio.pdf. Acesso em: 23 jul. 2020. 
ISSN 1981-3694

(DOI): $10.5902 / 1981369434252$

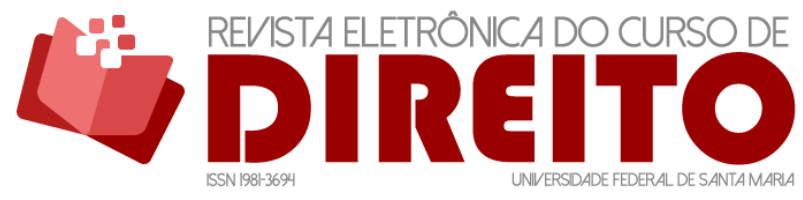

O DIREITO À AUTOIDENTIFICAÇÃO DOS POVOS INDÍGENAS COMO DIREITO FUNDAMENTAL

PEDRO PULZATTO PERUZZO

GIULIA OZI

\section{COMO FAZER REFERÊNCIA AO ARTIGO (ABNT):}

PERUZZO, Pedro Pulzatto; OZI, Giulia. O Direito à autoidentificação dos povos indígenas como direito fundamental. Revista Eletrônica do Curso de Direito da UFSM, Santa Maria, RS, v. 15, n. 2, e34252, maio./ago. 2020. ISSN 1981-3694. DOI: http://dx.doi.org/10.5902/1981369434252. Disponível em: https://periodicos.ufsm.br/revistadireito/article/view/34252. Acesso em: dia mês. ano.

Direitos autorais 2020 Revista Eletrônica do Curso de Direito da UFSM

Editores responsáveis: Rafael Santos de Oliveira e Angela Araujo da Silveira Espindola

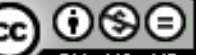

Esta obra está licenciada com uma Licença Creative Commons Atribuição-NãoComercial-SemDerivações 4.0 Internacional.

\section{SOBRE OS AUTORES}

\section{PEDRO PULZATTO PERUZZO}

Professor Titular Categoria A1 da PUC-Campinas. Membro do corpo docente permanente do Programa de Pós-Graduação stricto sensu em Direito (PPGD), vinculado à linha de pesquisa "Cooperação Internacional e Direitos Humanos". Membro do grupo de pesquisa "Direito num mundo globalizado" (CNPq/PUC Campinas). Na graduação, professor das disciplinas Direitos Humanos, Direito Penal Internacional e Metodologia Jurídica. Doutor (2015) e mestre (2011) em Direito pela Universidade de São Paulo-USP. Advogado graduado pela PUC-Campinas em 2007, consultor geral da Comissão de Direitos Humanos da Ordem dos Advogados do Brasil - seccional São Paulo (2019). Realizou, durante o doutorado, estágio em pesquisa na Faculdade de Educação da Universidade de Alcalá - Espanha - entre janeiro e fevereiro de 2015, pesquisando experiências de educação inclusiva de imigrantes e ciganos. Tem interesse em pesquisa empírica e experiência acadêmica na área de Direitos Humanos, com ênfase em Antropologia do Direito, atuando principalmente nos seguintes temas: direitos humanos, direito internacional, pessoa com deficiência, hanseníase, povos indígenas, minorias, democracia participativa, diálogo intercultural e desenvolvimento social.

\section{GIULIA OZI}

Advogada e Cientista Social, formada em Direito na Pontifícia Universidade Católica de Campinas e de Ciências Sociais na Universidade Estadual de Campinas. 